\title{
EI Señor Presidente y el vanguardismo surrealista 1
}

\section{Jorge Ramírez Carc ${ }^{f}$}

Un iversidad Naciona 1. Costa Rica

RESUMEN

EI Señor Presidente es un texto vanguardista, no según la modalidad europea, sino según la vertiente híbrida surgida en América Latina. La novela utiliza recursos y estrategias discursivas del surrealismo para redimensionar las experiencias subjetivas de unos personajes envueltos por la atmósfera pesadillesca y demoníaca de la dictadura. Como texto híbrido mezcla lo ajeno (vanguardias europeas y cristianismo) y lo propio (cultura maya-quiché); y su confluencia posibilita la colisión de tres estéticas: la corriente realista (realismo y regionalismo), el mundo animista maya-quiché y las vanguardias (surrealismo).

\section{ABSTRACT}

El Selior Presidente is a vanguard text, not in the European sense, but following the hybrid form appearing in Latin America. The novel employs resources and discourse strategies of surrealism to resize the subjective experiences of sorne characters enveloped in the nightmarish and demonic atmosphere of the dictatorship. As a hybrid text, foreign aspects (European vanguards and Christianity) are combined with their own (Mayan-Quiche culture); and their coming together leads to the collision of three esthetic codes: realist currents (realism and regionalism), the animist Mayan-Quiche world and the vanguards (surrealism).

\footnotetext{
Recibido: 30 de junio de 2009; aceptado: 25 de julio 2009.

Correo electrónico: caronauta@hotmail.com
} 
Palabrasclave: novela hispanoamericana, vanguardismos literarios, surrealismo, Miguel Ángel Asturias

Keywords: Spanish American novel, Iiterary vanguardisms, surrealism, Miguel Ángel Asturias

Entre la realidad y el sueño la diferencia es puramente mecánica. M. A. Asturias, El Señor Presidente.

Un vistazo a la lectura especializada sobre El Señor Presidente nos revela que el texto de Asturias ha sido inscrito en varios órdenes estético-ideológicos, poniendo de manifiesto lo inasible de la novela para 1 as clasificaciones de la crítica literaria; se ha dicho que es realista, regionalista, modernista y vanguardista. Todos esos asertos serían verdaderos siempre que se diga que en la novela predomina un collage estético y estilístico propio de las vanguardias latinoamericanas (y españolas). Dado que las lecturas anteriores, cuando señalan los aspectos vanguardistas en esta novela de Asturias, tienden a minimizarlos por no encaj ar en los postulados, manifiestos y doctrinas de la escuela de Bretón, planteo aquí una lectura en la que destaca el carácter continuista y constructivo de las vanguardias latinoamericanas en contraste con el rupturista y destructi vo de las vanguardias europeas. Mientras que allá se aboga por eliminar y despojarse de toda tradición estético-literaria anterior, acá se privilegian los lazos de rescate y conservación de las tradiciones culturales y las representaciones simbólicas de los antepasados con fines identitarios.

Antes de hablar del vanguardismo surrealista en El Señor Presidente ténganse en mente algunas premisas teóricas y metodológicas: 1. no se trata de hacer una traslación y una aplicación mecánicas del surrealismo bretoniano a la novela del guatemalteco; 2. no abordaremos la presencia de los elementos surrealistas en El Señor Presidente como productos de una influencia unidireccional europea 
en lo latinoamericano, sino como un trabajo consciente que nos convierte en centro desde donde se mira, se selecciona y se activan unos códigos estético-ideológicos de representación que emparentan con otros de la tradición cultural desde donde se mira, se asume y se trabaja lo ajeno con que se resaltará lo propio; con esto descartamos la sumisión y la recepción pasiva de los elementos surrealistas por parte de las redes culturales y simbólicas de la tradición cultural mayaquiché en la que se ubica Asturias; y 3. tener en cuenta el proyecto estético-ideológico que se había impuesto Asturias a la hora de abordar un problema tan realista como la dictadura desde los parámetros y la perspectiva surrealistas.

Estaría de más señalar, de acuerdo con Daniel Champion, que Asturias no se ajusta al surrealismo bretoniano, porque no se plegó a ningún manifiesto ni se adscribió a las doctrinas y métodos de trabajo avalados por Bretón. Sería más pertinente la lectura que plantea Elizabeth Aileen Benedict, para quien el surrealismo de Asturias se presenta según tres categorías: «imaginative enlargement of the universe, including myth, nahaulism, visionary foreshadowing, and insistence upon freedom of thought and fantasy; dreams, a favor technique, founded on the work of Freud and Jung, of the 1920' s surrealist group; and a style which involves the use of automatic writing, surrealist imagery, and onomatopoeia and wordplay» ${ }^{3}$. Según esa lectura, Asturias conjuga en su novela la herencia cultural mayaquiché con el surrealismo. Por esta razón, El Señor Presidente puede considerarse como un texto híbrido en el que se mezclan lo ajeno proveniente de las vanguardias europeas y lo propio asociado con la tradición étnica maya-quiché. Esta confluencia posibilita la colisión de tres estéticas: una proveniente de la corriente realista (realismo y regionalismo), otra que emana del mundo animista maya-quiché (lo mítico-mágico) y una tercera que procede de las vanguardias (surrealismo).

3

Daniel Champion. «Eye of Glass, Eye of Truth: Surealism in El Se/lar Presidellle», Hüpanic Joumalli, I (1981): 124. 
En mi lectura centraré la atención en el vanguardismo surrealista dél texto de Asturias, haciendo hincapié en aquellas marcas textuales y discursivas que vinculan al texto con un surrealismo heterodoxo.

Pese a que el texto se inscribe en el vanguardismo europeo, no ofrece un carácter iconoclasta, dogmático y ortodoxo, sino que presenta rasgos atenuados y diferentes a los que caracterizan a las manifestaciones europeas. Se encuentra en El Señor Presidente un matizado experimentalismo lingüístico con el fin de darle mejor legibilidad al texto y aumentar el contacto con el público lector; existe un expreso interés social que procura rescatar y reconstruir la identidad étnico cultural, razón por la cual no se puede hablar de una deshumanización, sino de una escritura de compromiso al instalarse en la realidad colectiva. En lugar de un apego incondicional a la escuela de Bretón, Asturias hace un uso instrumental de la expresión surrealista europea: «Para nosotros el surrealismo representó el encontrar en nosotros mismos no lo europeo, sino lo indígena y lo americano [... ], cuando cada uno empezó a registrarse por dentro se encontró con su inconsciente indígena... El surrealismo, para los escritores latinoamericanos y especialmente para mí, fue una gran posibilidad de independencia respecto a los moldes occidentales» ${ }^{4}$. Así, en su relación con las vanguardias europeas, Asturias no se acogerá pasivamente a sus lineamientos, sino que los recreará y reelaborará con recursos y procedimientos provenientes de su propia tradición simbólico cultural.

Por esta razón es fácil descubrir que en Asturias el lenguaje construye una realidad muy distinta en la que se fusionan y desaparecen los límites entre la ficción y la realidad, entre las experiencias oníricas y las experiencias reales, entre el mundo interior y el mundo exterior. Sus textos resumen, definen y plantean la coexistencia de los mundos indígena y ladino, lo real y lo maravilloso. Ocurre una pérdida del principio de identidad; todo parece salir de sí mismo y transformarse en algo próximo o en su contrario: la vida y la muerte,

4 Luis López Álvarez. COI/ I'er.mciolles COII Miguel Ángel Asturias (1974) (San José: EDUCA. 1976). 
lo real y lo imaginario, lo claro y lo oscuro, la realidad y el sueño dej an de ser contradictorios. Nos sumergimos en un collage estético y estilístico que atrapa todas las reali dades en una sola a través del idioma; ese idioma múltiple materializa la herencia hispánica y los giros propios de la tradición oral popular guatemalteca, remozada y recreada por el autor desde las nuevas técnicas surrealistas, y le otorga una connotación absolutamente ritual a su propio lenguaje. Asturias somete la lengua a múltiples procesos destructivos y constructivos para hacer aparecer nuevas palabras que provocan deleite sonoro-musical y semántico en el lector. Este nuevo lenguaje queda con frecuencia distorsionado, porque la fusión de los elementos integrantes no se ejecuta desde la razón sino desde una experiencia onírica, subjetiva, alucinante y mágica.

Asturias reconoce que los juegos urdidos por el surrealismo abren una puerta o fisura a través de la cual pasan codificados mensajes inconscientes propios de su subjeti vidad híbrida maya y ladina. Así surge lo que el propio autor denominó alguna vez «una especie de sueño, de irrealidad, que al contarse con todo detalle parece más real que la reali dad misma». Su surrealismo, según anota López $\bar{A}_{1-}$ varez «es más natural que el europeo, sin la presencia vigilante de la inteligencia y menos del razonamiento» 5 . Asturias consideró su escritura como realismo barroco, sin dej ar de reconocer los aspectos surrealistas que la conformaban : «Mi realismo barroco es 'mágico' porque depende un poco del sueño tal como lo concebían los surrealistas. Tal como lo concebían también los mayas en sus textos sagrados. Leyendo éstos me he dado cuenta que existe una reali dad palpable sobre la cual se enraíza otra, creada por la imaginación, y que se

5 Daniel Champion trascribe unas palabras de M. A. Asturias en las que descalifica el surrealismo europeo por ser demasiado intelectual y libresco, carente de una actitud vital y existencial: «Le suréalisme fran aise est tres intellectuell, tandis que dans mes livres, le surrélisme acquiert un caractere completement magique, completement différent. 11 ne s'agit pas d' une anitude intellectuel, mais d'une atútude vitale, existenÚelle. C'est l'atútude de l'Indien qui, avec sa mentalité primiúve et enfantine. confond le réel et I' imaginaire. le rédvet»le (124). 
envuelve con tantos detalles que se hace tan real como la otra. Toda mi obra se desarrolla entre esas dos realidades: la una social, popular, con personajes que hablan el habla del pueblo guatemalteco, la otra imaginaria, que los encierra en una especie de ambiente y paisaje de sueño».

El Señor Presidente, escrita entre 1922 y 1932 y publicada en México en 1 946, nos introduce a un mundo distorsionado y alucinante en el que los personajes deambulan en un clima que oscila entre el sueño y la realidad, entre la pesadilla y la felicidad, entre la vida y la muerte. La atmósfera está impregnada del miedo que produce la ausencia del tirano que por tal se hace más ubicua. En la figura del tirano se fusionan las tradiciones judeocristianas y maya-quiché, y resulta un ser demoníaco, divino y mítico que domina desde las sombras. Esta atmósfera se hace más próxima al lector al romperse-fusionarse las barreras entre la realidad y el sueño. Las diversas voces narrativas que intervienen hacen percibir este ambiente no de manera objetiva, sino subjetiva; además del narrador omnisciente, encontramos fluir de conciencia, sueños, delirios, pesadillas que fragmentan y subjetivizan la reali dad. Los personajes, por más que quieran escapar o librarse de la tiranía, yacen en un mundo estático que aprisiona y en un tiempo que va de lo más finito hacia una dimensión infinita que devora cualquier manifestación histórica.

Aunque el texto de Asturias apunta hacia una realidad externa, hacia un mundo fuera del texto, la perspectiva desde la cual es mostrado ese mundo es subjetiva. Esto hace que la realidad no se vea, sino que se experimente a través de la angustia y la desesperación de los personajes que viven sus pesadillas en el infierno de la dictadura. Aquí es donde se rompe el puente entre el texto y la realidad: la experiencia onírica y pesadillesca de los personajes hace dudar al lector de lo que lee. Los límites entre la realidad y el sueño no están bien definidos. Como lectores comenzamos a fluctuar entre una y otra orilla del mundo desenvuelto por el texto; aquello que creíamos que estaba fuera del texto termina siendo producido por el texto mismo que involucra al lector en la pesadi llaque sufren los personajes. De 
este modo se fragmenta la supeditación de la escritura a la reali dad y entramos en un ambiente en el que las fronteras se han suspendido: el espacio se vuelve elástico, el tiempo también se estira y se encoge y los personajes unas veces poseen una identidad y otras veces otra. Más que en una realidad extratextual, El Señor Presidente sumerge en ese mundo tejido y tramado por los diferentes juegos fónicos, las técnicas pictóricas y estéticas y las diversas perspectivas narrativas de las que echa mano.

El Sellar Presidente no es una novela realista ni histórica al modo del reali smo fotográfico y referencialista deci monónico. Sólo hay una mención a un acontecimiento histórico: la guerra de Verdún ${ }^{6}$ ), sino que se constituye en un collage estilístico propio de las vanguardias heterodoxas, tal como las caracteriza Bernal Herrera7• El mundo es autónomo frente a la reali dad exteri or mediante un lenguaje que pierde toda referencialidad, mas no así legibilidad; por encima de la anécdota prevalece una maquinaria verbal que configura la reali dad textual que involucra subjeti vamente al lector. No es la trama lo que predomina en el texto de Asturias, habitual en la novelística anterior al modernismo, sino el surgimiento y el trabajo de un lenguaje desdoblado que crea un mundo ambiguo y paródico, que fusiona aspectos de distinta naturaleza. Las marcas vanguardistas no se presentan aquÍ como en las vanguardias clásicas europeas, sino tal como éstas han encamado en nuestra realidad multiforme, híbrida y barroca. El mundo al que nos introduce el texto es el mundo de la ambigüedad y de lo paródico de las expresiones culturales de occidente ${ }^{8}$.

6 Miguel Ángel Asturias. El Se;ior Presidellte (1 946), 7" ed. (San José: EDUCA, 1988) 323. Todas las citas serán tomadas de esta edición. De ahora en adelante se indica la página después de la referencia.

7 Bemal Herrera, «Asturias y las vanguardias hispanoamericanas: ortodoxos y heterodoxos», Revista Ulliversidad de Sall Carlos de Guatemala, sn (1998).

8 Esos aspectos occidentales parodiados son la democracia y el cristianismo. El tirano se enmascara con las figuras representativas del poder político (presidente) y religioso (Dios-Jesús). La cosmogonía tradicional es invertida y saturada por la versión maya-quiché. El actuar de la Iglesia es reducido a espacios privados. Dios se ha vuelto impotente. Las plegarias sumen a los habitantes de este mundo en un tiempo y en un espacio insalvables. 
Esa ambigüedad y el carácter paródico los encontramos desde el mismo umbral de la novela: tanto el título como el primer capítulo nos introducen en un mundo donde las fronteras entre los niveles de la realidad se han suprimido para construir otra realidad diferente a la que tenemos codificada. Las palabras del título tienden a velar/develar la trabazón de las esferas política y religiosa implicadas en el mundo de la dictadura: tras la máscara de Presidente se oculta un sanguinario dictador que reclama sacri ficios humanos y se le concede una dimensión divina. El capítulo «En el portal del Señor» refuerza esta ambigüedad: «portal» y «Señor» connotan un ambiente sagrado que en el texto cultural connotan a Jesús. Con la marca plural del «Señor» del título, se abre la posibilidad de que ese mismo término se refiera tanto al Señor Presidente como a Dios. Lo político y lo religioso se interrelacionan y se hacen reversibles: el Presidente es asimilado a Dios y a Jesús al evocarse el portal.

Además, el primer párrafo de la novela no sólo introduce a un mundo dominado por las sombras y habitado por el príncipe de las tinieblas, Luzbel, sino que el juego de palabras permite ver la reversibilidad de «la luz en la sombra» y «la sombra en la luz» (p. 9) como en la banda de Moebius. Esto no sólo transforma el espacio ciudad en un mundo pesadillesco, sino que también incidirá en la transformación de los espacios cosmológicos de la teogonía tradicional : aunque configurado como un purgatorio-infierno, el mundo de la dictadura no posee las características de calor o de fuego que tiene en la tradición judeocristiana y católica, sino de espacios fríos donde los condenados tiritan. Así, este pórtico de entrada cumple una función proyectiva: instaura y configura los ejes sobre los que se va a mover el mundo narrado de modo ambivalente y rompe con las fronteras de la realidad social y simbólica que conocemos 9 .

9 Ver Jorge Ramírez Caro. «La impotencia de Dios en el infierno de la dictadura y la (unción subvertidora de lo erótico en El Señor Presidente», /Delliddad Celllroamerical/Q 5 (mayo, 2 (O) 55-70. 
La visión pesadillesca se refuerza con la estructura cíclica del texto y la temporalidad en la que se sumergen los personajes. El texto no sólo termina donde comienza, en el Portal del Señor, sino que su territorio interior, la ciudad, se propone como laberinto sin salida. Este espacio pierde sus antiguas características y adquiere otras totalmente ajenas a la lógica reali sta. Se vuel ve elástico y contráctil, las fronteras se esfuman y desmaterializan, como cuando el Pelele desea huir «como el que escapa de una pri sión cuyos muros de niebla a más correr, más se alej an» (p. 27), o se contraen y acorralan, como en la

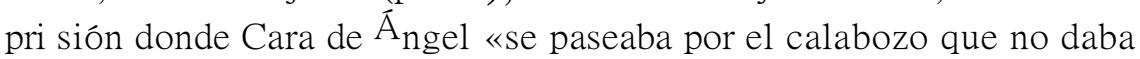
para cuatro pasos» (p. 401). Además, el espacio posee una fuerza centrípeta que controla toda posibilidad de fuga: el tren en el que Pelele sueña dar un paseo «volvía al punto de partida como un juguete preso de un hilo» (p. 30). Igual sucede con Cara de $\bar{A}_{\text {ngel: desea }}$ escapar de la desgracia, pero su tren lo lleva precisamente a las manos de Farfán y de ahí a lo más oscuro de las celdas de la dictadura (pp. 377-386).

Esta imagen del espacio como retentivo-carcelario guarda estrecha relación con la figura del dictador, caracterizado con dos imágenes que expresan el control y la manipulación: la de la araña que teje su tela y la del titiritero. Así como el tren de Pelele está atado a un hijo y el destino de Cara de $\bar{A}_{\text {ngel es terminar enredado en las telara- }}$ ñas de la celda 17, del mismo modo todos los habitantes de este mundo son vigilados y controlados por medio de «Una red de hilos invisibles, más invisible que los hilos del telégrafo, comunicaba cada hoja con el Señor Presidente, atento a lo que pasara en las vísceras más secretas de los ciudadanos» (p. 56). No hay nadie que se mueva con voluntad propia y aquel que pretenda ponerse al margen del poder termina enredándose en sus propios pasos.

Una forma de poner de manifiesto el efecto desquiciador de la dictadura sobre la vida humana es tomar como eje estructural de la narración el punto de vista de seres carentes de sus facultades mentales, cuestión que enlaza al texto con el vanguardismo surrealista. Como 
señala Joaquín Marco, la figura clave de la narración es un idiota en cuya mente se confunde la realidad y la imaginación, las imágenes míticas procedentes del sustrato indígena y la experiencia religiosa católica popular. De la mente de este idiota surgen imágenes irracionales, juegos de palabras o elementos puramente fónicos 10. El texto valora la manifestación de lo irracional-ilógico-infantil, sobre lo racional-lógico-adulto. Como ejemplos están el Pelele infanti lizado, la disputa entre el titiritero y su mujer cuyo acuerdo es «no entraren razones» (p. 76) y el plan concertado por Vásquez y Cara de $\bar{A}_{\text {ngel }}$ para ayudar a escapar al general Canales. $S$ obre este plan el narrador señala: «Un tonto, un loco y un niño no habrían concertado tan absur- do plan. Aquello no tenía pies ni cabeza» (p. 100).

La importancia de lo irracional se manifiesta mediante los sueños y las pesadillas de los personajes. Los sueños del Pelele, Cara de

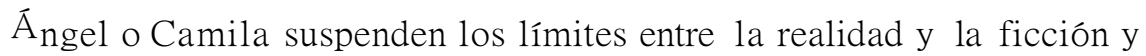
entran en un territorio donde se borran todos los contrarios y los mundos se fusionan. El sueño, en este caso, aparece como recurso para crear armonía. El del idiota lo conduce a la felicidad perfecta: estar en los regazos de la madre y ella convertirse en espejo-eco del hijo. En este mismo sueño se llegan a fundir las visiones mítica indígena con la j udeocristiana, cuando en voz del pájaro se conjugan todas las mitades, la verdad y la mentira, la realidad y la ficción : «i Soy rosa y soy manzana, doy a todos un ojo de vidrio y un ojo de verdad: los que ven con mi ojo de vidrio ven porque sueñan, los que ven con mi ojo de verdad ven porque miran ! iSoy la vida, la Manzana-Rosa del Ave del Paraíso; soy la mentira de todas las cosas reales, la realidad de todas las ficciones !» (p. 34). El sueño y sólo el sueño es el único medio por el cual Pelele accede a la completa felicidad que le tiene negada la terrible realidad: «Sentíase feliz desde la puntita de la lengua hasta la puntita de los pies» (p. 36).

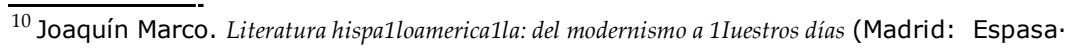
Ca1pe. 1987).
} 
El capítulo xxI narra, a manera de contrapunto, el sueño de Cara

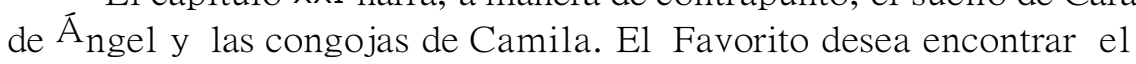
sueño perfecto, que lo ayude a evadirse de los problemas que hasta ese momento se ha comprado, un sueño que lo rescate de lo que presagia, un sueño que le ayude a llegar a la verdad: «Venía a olvidar, a dormir, a no ser. Ya no más razones montables y desmontables como las piezas de una máquina. A la droga con los tomillos del sentido común. Mejor el sueño, la sinrazón... » (p. 200. El destacado es mío). La negación del ser se compara con la negación del sentido común y la razón dentro de la lógica cartesiana: se busca la suspensión de las facultades mentales para ingresar a una lógica narcotizante y reparadora de toda la integridad de un ser antes escindido. Este sueño de Cara de $\bar{A}_{\text {ngel provoca ideas y pensamientos inconexos, insertos en }}$ el fluido de la conciencia. Al final, termina conduciéndolo a lo que se iba a derivar de su ayuda a Canales y de su noviazgo con Camila: «cavaba su propia sepultura» (p. 205 ). El sueño se le presenta como una barca que surca los mares de la realidad para adentrarlo a un mundo más allá de este mundo (especie de Caronte). Pero la barca del sueño no sólo lo recoge a él, sino también a Camila y a su vez se concluye con el descubri miento de la verdad: «ponedla, si hay lugar, en la barca de las enamoradas que no serán felices» (p. 207). El sueño de ambos los lleva al mundo contrario del imaginado, descubriendo su propio destino e incursionando con anticipación en esa otra realidad que les espera: él morirá y ella no será feliz.

Pero la experiencia onírica no sólo se presenta para armonizar o esclarecer, sino también para manifestar las catástrofes sicológicas derivadas de un poder que espía a todo mundo y que cuenta con la complicidad de todos para delatar a los otros. Las pesadillas y los delirios que sufren el Pelele, Rodas y Cara de $\bar{A}_{\text {ngel ejemplifican el }}$ mundo agónico de los que viven bajo el temor de la muerte en el infierno de la dictadura. Después de haber eliminado al Pelele, a Genaro Rodas lo persigue un ojo en sus sueños ( «los que ven con mi ojo de vidrio ven porque sueñan»). Este ojo de vidrio posee facultades 
anímicas sujetas a la ausencia o presencia de luz. Por ejemplo, en la oscuridad se hace más grande y se contorsiona con la luz o al pasar de la luz a la oscuridad: «El ojo se hizo un ocho al pasar de la claridad a la tiniebla» (p. 86).

En el capítulo XXVI no sabemos qué ocurre primero: si el delirio de Camila o la pesadilla del Favorito. El narrador señala desde el inicio: «Entre la realidad y el sueño la diferencia es puramente mecánica». Esto nos introduce en la duda: no sabemos si el delirio de Camila está al interior de la pesadilla de Cara de $\bar{A}_{\text {ngel o si es otra }}$ experiencia aparte, por eso el narrador dice que se trata de un «luego de sueños» (p. 253). Este capítulo capta el fluir de conciencia delos personajes del que se derivan imágenes irracionales, juegos de palabras, elementos puramente fónicos, mezcla de pensamientos eróticos-sexuales con oraciones religiosas, imágenes pictóricas surreales, ideas inconexas, es decir, toda una galería de imágenes emergentes del territorio oscuro del inconsciente. Por ejemplo: «La risa se desprende de los dientes negruzca, bestial, pero el contacto del aire se mezcla al vapor de agua y sube a formar las nubes... Cercas, hechas con intestinos humanos, dividen la tierra... Las costillas de un caballo sirven de violineta al huracán que sopla» (p. 158). Este capítulo se titula «Torbellino» y todo resulta ser un «sueño sin hilván» (p. 257) donde, contrariamente, el lector encuentra una historia concatenada. Lo único que sucede al revés es la visualización de la muerte de los

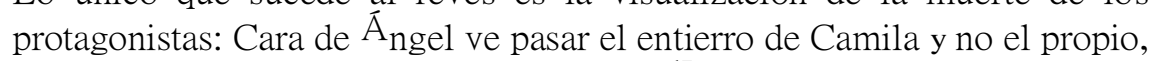
como en el intertexto de Don Juan Tenorio ${ }^{1 I}$.

La experiencia onírica es la que otorga un poder envolvente y subjetivo a la atmósfera pesadillesca predominante en el mundo de la dictadura. El binomio sueño-realidad hace pensar en la parej a vidamuerte, existencia-inexistencia. El sueño hace desaparecer todo lo

11 Margarita Rojas señala las similitudes y diferencias entre Cara de Ángel y Don Juan Tenorio: a ambos el amor lostransfonna positivamente; estánasociadosal infierno; pero mientras a Don Juan lellegala salvación eterna, el Favorito se hunde en las tinieblas del infierno dela dictadura; «El Señor Presidente: el teatro de un demonio escondido», Taller de Letras 31 (2002): 12 5-139. 
que rodea a los personajes y los sumerge en otra reali dad mucho más compleja, en otra vida que está ahí mismo en la vida. Tal experiencia abre ese otro mundo que colma a los habitantes del mundo de la dictadura. Por ejemplo, Camila enferma pierde toda noción de la realidad externa a sí y de sí misma, se experimenta por encima de todas las cosas, pero sin dejar de experimentarlas dentro de sí:

Camila se preguntaba si era ella la que iba andando. Los pies le quedaban grandes, las piernas como zancos. Andaba fuera del mundo, con los ojos abiertos, recién nacida, sin presencia. Las telarañas espumaban el paso de los fantasmas. Había muerto sin dejar de existir, como en un sueiio, y reviviajuntando lo que en realidad era ella con lo que ahora estaba soñando. [...] Era y no era ella la que iba andando. Sensación de volver a la vida en otra vida. Hablaba de ella como de persona apoyada en bastón de lejanías, tenía complicidad con las cosas invisibles y si la dej aban sola se perdía en otra, ausente... (pp. 339-340. Los destacados son míos).

Existen numerosos aspectos lingüísticos que vinculan a $E l$ Señor Presidente con otras prácticas vanguardistas. Mencionemos los reiterados juegos de palabras; términos conocidos son sometidos a procesos de descomposición y composición para recomponer uno nuevo que puede cumplir varias funciones dentro del texto: INRI, por adición y encadenamiento, se recompone en INRIdiota (p. 28). Lo mismo sucede con Jesucristo de donde resulta Jesupisto (p. 19). Este procedimiento cumple unafunción paródica: se aprovecha la estructura de una palabra de orden sagrado-religiosa para someterla a un rebaj amiento de orden moral-psicológico, en el primer caso, y para fusionarla con elementos con los que tradicionalmente se presenta divorciada, lo material-económico, en el segundo. Otras veces se utiliza la repetición y el encadenamiento de sonidos para dar la idea de una carcajada colectiva (p. 13) o para reproducir el quejido-dolor del 
idiota (p. 28) o el dolor de ovarios de la prostituta (p. 230), o la onomatopeya de la risa de la Chabelona (p. 125), o las de Cara de $\bar{A}_{\text {ngel }}$ y el Señor Presidente con el fin de hacer evidente el nerviosismo de los personajes o la desesperación (p. 320), como en el caso de los

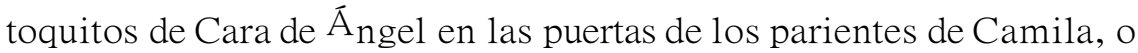
los hij hij, hij de Fedina para indicar el llanto (p. 210), o los le, le, le de la esposa de Carvajal para expresar la parálisis-mudez verbal y el terror frente a los centinelas de hielo (p. 309).

En otras ocasiones no sólo se repiten sonidos y palabras, sino también oraciones que indican la parálisis e imposibilidad de salir del espacio o de llegar a alguna parte en este mundo infernal . La mujer de Carvajal reclama al cochero que dé más rienda a los caballos para llega a tiempo de socorrer a su esposo: «Pero el vehículo no rodaba, ella sentía que no rodaba, que las ruedas giraban alrededor de los ejes dormidos, sin avanzar, que siempre estaba en el mismo punto» (pp. 309-3 10). Es similar lo que le sucede a Cara de $\bar{A}_{\text {ngel en su }}$ viaje en tren: entre la vigilia y el sueño tiene «la sensación confusa de ir en el tren, de no ir en el tren, de irse quedando atrás del tren, cada vez más atrás del tren, más atrás del tren, más atrás del tren, más atrás del tren, cada vez más atrás, más y más cada ver cada vez, cada ver cada vez, cada ver cada vez, cada ver cada vez, cada ver cada ver cada ver cada ver cada verp, 382). En este caso, el sueño es premonitorio, ya que el personaje vive con anticipación su destino final de cadáver de araña seco que ha caído en la telaraña del poder (pp. 407408): el juego de sustitución de cada vez por cadáver permite que el lector visualice el halo de muerte que rodea a la figura del Favorito. Lo que sucede con estos dos personajes, le ocurre al resto de los sometidos por la dictadura: los creyentes se sumergen en sus interminable CÍrculos de oraciones que repiten y repiten sin poder alcanzar ningún favor de su Dios impotente (p. 158): no sólo es maligna la sombra en la que se oculta la dictadura, sino también el silencio con que Dios condena a sus fieles.

Tanto las categorías de los personajes como las espacio-temporales pasan por una transformación al leer el texto desde esa atmósfera 
de sueño y pesadilla, de parálisis e inmovilidad, de encierro y de laberinto, de impotencia y de vacío que experimentan los personajes. Los personajes no remiten a referentes extratextuales ubicados en la reali dad histórico concreta, sino a elementos simbólicos ubicados en el texto cultural; el Señor Presidente no sólo representa la figura de un mandatario constitucional y democráticamente elegido, sino también la de un tirano, la de un Dios, la de un Demonio y la de una

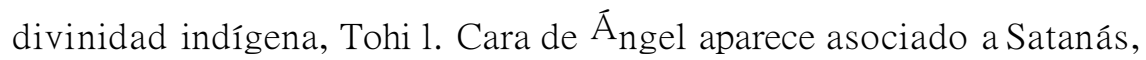
a Jesucristo y a Don Juan. Camila se equipara a la Virgen y a Doña Inés. El Pelele y el Mosco son asociados al Jesús crucificado. Hemos dicho que la imagen de la ciudad no es sólo la del laberinto, sino también la del purgatorio-infierno, razón por la cual las últimas palabras de la novela son las de una oración que pide «Por las benditas almas del Santo Purgatorio... Kyrie eleison ... » (p. 413).

En relación con el tiempo, se presentan dos concepciones: una lineal o histórica - $\mathbf{1}$ a revolución de Canales - que desea sacamos del tiempo cíclico y perpetuo en el que domina el tirano. Pero aquel tiempo es desactivado-anulado y el mundo tennina sumergido en un tiempo mítico circular. Esta sensación de ingresar a un tiempo eterno y suspendido de cualquier medición nos la da la estructuración del texto en tres partes que transitan desde el tiempo más concreto (2 1, 22 y 23 de abri 1, la pri mera parte, 24, 25, 26 y 27, la segunda), hasta desembocar en un tiempo inconmensurable que se traga-devora aquellas partes pequeñas (las semanas, los meses y los años de la tercera parte). Así, las experiencias oníricas no sólo distorsionan las c ategorías de los personajes, sino también las espacio-temporales y nos permiten tener la sensación de ingresar en las tinieblas controladas y regidas por el Demonio generado por la fusión de una doble vertiente: la cristiana occidental y la maya-quiché.

En El Señor Presidente se pone de relieve el cómo se cuenta sobre el qué se cuenta; se ponen de manifiesto los mecanismos y procedimientos discursivos por sobre el contenido de lo contado. Veamos los procedimientos irónicos que nos ubican al interior de 
otro tipo de realidad. Tomemos como puntos de partida los nombres de algunos capítulos; el rótulo que etiqueta cada capítulo nos sugiere una reali dad muy di stinta de la que termina tratándose. Recuérdese 1o dicho sobre el título de la obra y sobre el rótulo del primer capítulo. Tomemos como ejemplo otros epígrafes. «Ese animal» (V) no se refiere a una bestia en particular ni es el insulto sobre alguien cuya actitud sea censurable por atroz, sino las palabras que recaen sobre un viejito que por derramar el tintero del escritorio del Señor Presidente recibe una paliza de doscientos palos que no aguanta. «Absolución arzobispal» (VI) enmarca la pasividad y complicidad de la Iglesia con el mundo de muerte desplegado por la dictadura: no interviene en la solución de los problemas de los mendigos que se acogen baso su sombra, pero i rónicamente está vigilante para abrirles las puertas del Reino de Dios: la Iglesia se preocupa más por salvar el alma que por salvar el cuerpo de los mendigos. Por el contexto en que aparece el capítulo XVI, la huida-fuga de Canales y el rapto de Camila por

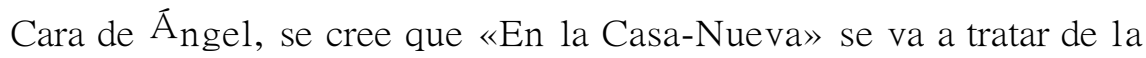
residencia donde se aloj arán los fugitivos, pero se refiere a la cárcel donde es recluida Niña Fedina, de ahí pasará a las casas malas o El Dulce encanto, centro de solaz sexual donde arriban los defensores de la dictadura. «El viaje» (XXXVIII) hace suponer al lector que Cara

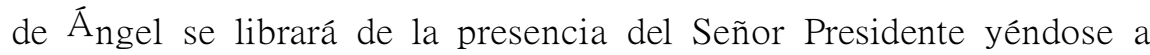
Nueva York, pero adonde llega es a la celda 17. Y «Parte sin novedad» (XLI) vuelve a enganchar al lector en la idea del viaje trunco del capítulo XXXVIII y le hace suponer que ahora se cumpliría, pero a lo que se refiere es a la muerte del Favorito en el pozo de su celda: la partida

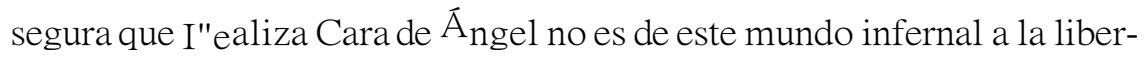
tad, sino del infierno a la muerte como una irredenta alimaña.

En cada uno de estos capítulos el lector experimenta una deserción de sentido, porque la lógica que organiza y estructura la narración está fuera de las posibilidades de ser aprehendida racionalmente. Si uno se orienta desde una perspectiva reali sta y espera que la trama se resuelva positivamente, sin ningún tipo de contrariedad y 
contradicción, constantemente tendrá que abandonar ese enfoque para entrar en una lógica de percepción subjeti va y subconsciente, donde son más frecuentes las inconexiones y las metáforas asociativas que no poseen la coherencia lógica propia del discurso tradicional. Además de la ironía que condensan estos capítulos, muchos no se refieren a lo que el epígrafe indica; por ejemplo, el capítulo XXIV se llama «Luz para ciegos» y está despojado de todo principio de causalidad, de toda lógica, además de que se refiere a la convalecencia de Camila y a la visita que hace con Cara de $\bar{A}_{\text {ngel a los baños. El lector espera }}$ encontrar unos ciegos iluminados por una luz especial. Al no hall ar nada de eso, no se puede olvidar que una constante del texto es la ambiguiedad mediante el uso de palabras plurales, como sucede con el mismo título de la novela.

Por último, téngase en cuenta el carácter pictórico para resaltar otros aspectos vanguardi stas de El Señor Presidente. Así como el lenguaje acentúa las características plásticas que buscan trasmitir las sensaciones que se experimentan ante la realidad y no la realidad misma, de igual modo las imágenes pictóricas nos permiten tener una experiencia subjetiva del mundo textualizado: impactan emotiva y sicológicamente al lector y lo involucran en aquel mundo donde toda frontera se ha perdido. La descripción de los personajes, los elementos naturales y celestes no buscan captar la mera superficie, sino que a ese elemento real y exterior se le añade otro elemento proveniente de la experiencia onírica, de donde resulta una nueva realidad en la que se yuxtaponen lo familiar y lo desconocido. La fusión de ambos produce un efecto fantástico; vacilamos, dudamos y fluctuamos ante y frente aquella nueva realidad que no podemos aprehender racionalmente, razón por la que nos desconcierta: «Medio en la realidad, medio en el sueño, corría el Pelele perseguido por los perros y los clavos de lluvia fina... seguía adelante, como el que escapa de una prisión cuyos muros de niebla a más correr, más se alejan» (pp. 2627. Los destacados son míos). Esta imagen de un espacio vivo, elástico, contráctil, procede de ese estado intermedio entre la realidad y el 
sueño: son más frecuentes estas imágenes en los capítulos o en las partes donde se narra una experiencia onírica o se vive la pesadilla de la persecución, como el caso del Pelele. Para este ser angustiado no hay horizonte posible: «Los horizontes recogían sus cabecitas en las calles de la ciudad, caracol de mil cabezas» (p. 27). El terror se hace tan gráfico en este personaje que cuando lo encuentra el leñador en el basurero sus «palpitaciones formaban gráficas de angustia a través de sus gritos y los ladridos del can, como el viento cuando entretela la lluvia» (p. 37).

Muchas de las imágenes plásticas en El Señor Presidente guardan rel ación con la pintura surrealista, en particular con la obra de

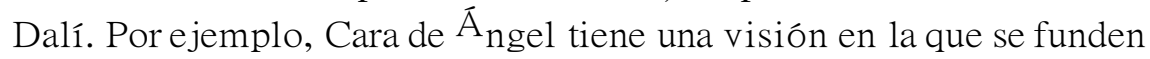
varias imágenes inconexas que ponen de manifiesto la experiencia onírica que hace converger visiones extrañas y pesadillescas con elementos de la fantasía y de lo cotidiano: «Por todos los poros de la Tierra, ala cuadrangular, surge una carcaj ajaj ada interminable, endemoniada... No es de noche y la sombra le separa de Camila, la sombra de esa carcaj ada de calaveras de fritanga mortuoria... La ri sa se desprende de los dientes negruzca, bestial, pero el contacto del aire se mezcla al vapor de agua y sube a formar las nubes... Cercas, hechas con intestinos humanos, dividen la tierra... Lejos, hechos con ojos humanos, dividen el cielo... Las costillas de un caballo sirven de violineta al huracán que sopla... Ve pasar el entierro de Camila... Sus ojos nadan en los espumarajos que van llevando las bridas del río de carruajes negros... Detrás del entierro canta un osario de caderitas de niño... Iliacos con ojos en forma de oj ales» (pp. 257-258). De estas descripciones queda excluida cualquier posibilidad de contemplación exterior de la realidad perceptible con los sentidos. La experiencia de los sueños se vuelve omnipotente en ese mundo mostrado y como lectores sufrimos una aprehensión y un engaño de los sentidos.

Cuando relata la experiencia pesadillesca de Rodas con elojo de vidrio y el efecto que esto tiene en Niña Fedina, el narrador señala: «El grito de su esposabañó de puntitos negros el fantasma de la muerte, 
puntitos que marcaron sobre la sombra de un rincón el esqueleto. Era un esqueleto de mujer, pero de mujer no tenía sino los senos caídos, flácidos y velludos como ratas colgando sobre la trampa de las costillas» (p. 84). Esto pone al descubierto, como en una xeroscopia, lo no visible al ojo humano. Al igual que en el sueño de Cara de $\bar{A}_{\text {ngel, }}$ estamos ante una situación que devela la realidad trágica de la existencia de los personajes en el mundo de la dictadura. A una situación de agravamiento psicológico le acompaña una situación de desmejoría física. Los personajes quedan frente a su propia ruina, visualizan su propio porvenir ya sea a través de sus sueños o de sus pesadillas. $\mathrm{Su}$ propio cuerpo se convierte en trampa, en lugar donde reside la vida y la muerte, la salvación y la condena. Véase la colisión de estos elementos en sí mismos; produce espanto, desespero y paranoia. El poder omnipotente del tirano y el mecanismo a través del cual se manifiesta el miedo- deja al descubierto la condición frágil y mor- tal de los personajes sujetos por los hilos del que todo lo sabe y todo lo controla.

Otras imágenes permiten visualizar a los personajes que parecen esfumarse o descompletarse frente a sí mismos. Por ejemplo, a Camila «Los pies le quedaban grandes, las piernas como zancos. Andaba fuera del mundo, con los oj os abiertos, recién nacida, sin

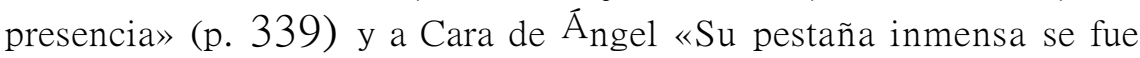
desprendiendo del más alto de los volcanes, se extendió con movimiento de araña de caballo sobre la armadura de la ciudad» (p. 342). A través del tamiz de las experiencias oníricas, los personajes experimentan un efecto de desajuste con su propio cuerpo, en el caso de Camila y una incontrolable desmesura de una de sus partes, en el

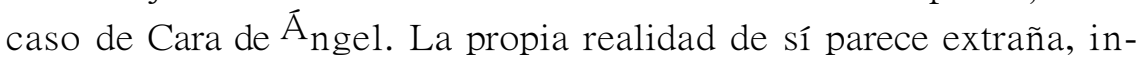
compatible. El propio cuerpo se supone inútil pordesproporcionado y desnaturalizado ${ }^{12}$, Todas estas imágenes tienen la función de deformar

\footnotetext{
$\overline{12}$ Aunque El Seiior Presidellle fue publicada en 1946, la imagen que se presenta de Camila con unas piernas desproporcionadas me recuerda un cuadro de Dalí de 1948: Los elefallles, animales que aparecen con unas pataslargas y flacas, como las de un flamenco, que difícilmente podrían sostenerlos, máxime que cada uno lleva un peso adicional al propio: una torre.
} 
la realidad, romper la lógica con la que estamos habituados a percibirla y proporcionamos una experiencia i rracional del mundo. El mundo cotidiano funciona aquí según la lógica del inconsciente que todo lo trasmuta. Lo que se muestra no es una realidad plana, sino una suerte de mundo reversible, que nos lleva de fuera a adentro, colocándon ${ }^{\mathrm{O}_{\mathrm{S}}}$ frente a los rostros plurales de la realidad experimentada: siempre nos encontramos frente a un objeto que resulta ser otra cosa totalmente distinta, provocándonos un engaño visual, como cuando los temeros «mamaban praderas transformadas en líquido blanco» (p. 344).

La novela de Asturias somete la realidad a infinitas distorsiones que hace difícil encasill arlo dentro del realismo tradicional : retoma y reelabora elementos de las vanguardias y de la cultura tradicional maya-quiché y de la cristiana occidental que hacen difícil también emparentarlo con las manifestaciones vanguardistas clásicas u ortodoxas. Como lo afirma José Miguel Oviedo, en El Señor Presidente se mezclan las técnicas de vanguardia y el cifrado lenguaje simbólico de la mitología indígena para crear no una representación realista o histórica de la dictadura, sino una deli berada deformación o exageración de la misma; para un exceso de poder una retórica excesiva que intenta recrear la monstruosidad física y la degradación moral del ambiente con técnicas expresionistas, raros giros sintácticos, imaginería surrealista y efectos discordantes ${ }^{13}$. El uso de estas técnicas está hecho de modo consciente, dinámico y creativo, de manera que no hay sumisión y dependencia de los moldes europeos para tratar la materia novelada ${ }^{14}$. Asturias aprovecha los aportes del surrealismo para construir los efectos psicológicos y subjeti vos de un problema

$1^{3}$ José Miguel Oviedo, Historia de la literatura hispa1loamerica1la. Posmodernismo, Va1lguardia. Regio1LaLISMO, Vol. 3 (Madrid: Alianza Editorial. 2(O 1).

$1^{4}$ Recuérdeseque Bretón, como pontífice del surrealismoortodoxo, no permitia que sus seguidores escribieran sobre lo que se les ocurriera; habia un programa, una doctrina $y$ un manifiesto. Asturias no se ajusta a esos criterios; actúa con toda libertad frente a la poética vertical del francés, razón por la que se permite parodiar sistemas amplios como el democrático y el cristiano-católico. 
social y reali sta como es la dictadura: desde que entramos al texto nos alcanza la atmósfera tenebrosa y pesadillesca de quienes lo habitan, sin esperanza humana ni di vina que pueda rescatarlos. Por más proyectos que se tengan para salir de aquel infierno, nadie puede salvar a nadie de lo que se genera en el mundo del inconsciente; tarde o temprano aparecen todas sus sombras y sus fantasmas y lo arrastran al mundo de las tinieblas. 